\title{
Our Experience of Epidural Anesthesia for Cesarean Section in Pregnant Woman with Corrected Tetralogy of Fallot: A Case Report
}

\author{
Düzeltilmiș Fallot Tetralojisi Olan Gebede Sezaryen İçin Epidural Anestezi \\ Deneyimimiz: Olgu Sunumu
}

Gamze KÜÇÜKOSMAN $\mathbb{D}$, Bahar SAY

Zonguldak Bülent Ecevit University Faculty of Medicine, Department of Anesthesiology and Reanimation, Zonguldak, Turkey

ORCID ID: Gamze Küçükosman 0000-0001-5224-0258, Bahar Say 0000-0001-8083-1039

Cite this article as: Küçükosman G and Say B. Our Experience of Epidural Anesthesia for Cesarean Section in Pregnant Woman with Corrected Tetralogy of Fallot: A Case Report. Med J West Black Sea. 2021;5(2):298-300.

Corresponding Author Gamze Küçükosman

E-mail

gamzebeu@gmail.com

\begin{abstract}
Tetralogy of Fallot (TOF) is the most commonly encountered cyanotic congenital cardiac disease in pregnancy. While most pregnancy cases after surgical repair of TOF have focused on cardiovascular and obstetric concerns, few authors have focused on anesthetic management strategies. Determining the type of anesthesia in these patients is very difficult, and current recommendations are based solely on reported pathophysiological concepts and clinical experiences. In this case report, we aimed to share our epidural anesthesia experience for cesarean surgery in a 37-week pregnant woman with corrected TOF surgery. In conclusion, we suppose that application of epidural anesthesia with divided and increasing doses of slow-acting bupivacaine in pregnant women with repaired TOF is a safe alternative to achieve good anesthesia with effective cardiovascular stability.
\end{abstract}

Keywords: Corrected tetralogy of Fallot, Epidural anesthesia, Caesarean Section

öz

Fallot tetralojisi (TOF) gebelikte en sık karşılaşılan siyanotik konjenital kalp hastalığıdır. TOF'un cerrahi onarımından sonraki gebelik olgularının çoğu kardiyovasküler ve obstetrik kaygılara odaklanmışken, nispeten az sayıda yazar anestezik yönetim stratejilerine odaklanmıştır. Bu hastalarda anestezi seçimi çok zordur ve güncel öneriler sadece bildirilen klinik deneyimlere ve patofizyolojik kavramlara dayanmaktadır. Bu olgu sunumunda düzeltilmiş TOF cerrahisi geçiren 37 haftalık gebede, sezaryen cerrahisi için uygulanan epidural anestezi deneyimimizi paylaşmayı amaçladık. Sonuç olarak, TOF onarımı olan gebelerde bölünmüş ve artan dozlarda yavaş etkili bupivakain ile epidural anestezi uygulamasının, etkili kardiyovasküler stabilite ile iyi anestezi elde etmek için güvenli bir alternatif olduğunu düşünüyoruz.

Anahtar Sözcükler: Düzeltilmiş fallot tetralojisi, Epidural anestezi, Sezaryen 


\section{INTRODUCTION}

Tetralogy of Fallot (TOF) is characterized by the presence of a ventricular septal defect, aortic overriding, pulmonary artery outflow obstruction and right ventricular hypertrophy. It is a classical and the most ordinarily encountered $(10 \%)$ cyanotic congenital cardiac lesion in pregnancy (1). Therefore, for successful anesthetic management in such a patient, it is important to know the physiological changes that occur during pregnancy, as well as having detailed knowledge of the underlying pathophysiology and the current degree of cardiovascular impairment (2). In this case report, we aimed to share our experience with epidural anesthesia for cesarean surgery in a 37-week pregnant woman who had corrected TOF surgery.

\section{CASE REPORT}

Written informed consent was obtained from the patient. A 32-year-old, $72 \mathrm{~kg}$ pregnant woman who was in her 37 th gestational week was referred to the anesthesia service to be evaluated before elective cesarean delivery. It was learned that the patient underwent complete correction surgery for TOF at the age of 4 and an appendectomy at the age of 12 , and she did not use any medication other than iron and vitamin supplements that were initiated during pregnancy. The physical examination findings of the patient were normal. On airway examination, the thyromental distance was found to be greater than $6.5 \mathrm{~cm}$, the incisor distance was greater than $3 \mathrm{~cm}$, and Mallampati class II with full range of neck movements. Right bundle branch block was seen on the electrocardiogram. The preoperative biochemistry values, hemogram, coagulation panels and blood gas measurements were within normal limits. The echocardiography (ECO) revealed normal left ventricular wall movements, a $13 \mathrm{mmHg}$ average gradient on the pulmonary valve, right heart cavities were severely dilated, there was mild to moderate tricuspid insufficiency, and a systolic pulmonary artery pressure of $32 \mathrm{mmHg}$ was evident.

Standard anesthesia monitoring [ECG, noninvasive blood pressure and pulse oximetry $\left.\left(\mathrm{SpO}_{2}\right)\right]$ was performed in the operating room. Invasive blood pressure (IBP) monitoring was provided by left radial artery cannulation. For infective endocarditis prophylaxis, Ampicillin $2 \mathrm{~g}$ iv was administered to the patient 30 minutes before surgery. Her blood pressure was $120 / 75 \mathrm{mmHg}$, heart rate was $118 / \mathrm{min}$, and $\mathrm{SpO}_{2}$ was $94 \%$. Oxygen was supplied with a face mask. After the epidural catheter (18 G) was inserted on the L3-4 level in the sitting position, the patient was positioned slightly in the left lateral decubitus position. As a test dose, $2 \mathrm{ml} 2 \%$ lidocaine without adrenaline was applied through the catheter. After the test dose, when motor and sympathetic blockage was not seen, $5 \mathrm{~mL}$ of $0.5 \%$ bupivacaine and $50 \mu \mathrm{g}$ fentanyl were applied via the catheter. A total of $14 \mathrm{~mL} 0.5 \%$ bupivacaine was administered at increasing doses within 30 minutes in 5-minute intervals until sensorial loss reached the T5-6 level. No change in the patient's hemodynamics had occurred during this time. A vasopressor agent was not used. After the birth, Methylergonovine maleate $0.2 \mathrm{mg}$ im was slowly administrated. During the operation, a total of $2000 \mathrm{~mL}$ crystalloid infusion was provided. The estimated blood loss was $450 \mathrm{~mL}$. Her heart rate ranged from 80 to 120/min with a mean blood pressure between 86 and 107 $\mathrm{mmHg}$ and saturation of $92-95 \%$. For postoperative analgesia, $3 \mathrm{mg}$ morphine was administered through the epidural catheter. There were no postoperative complications and additional analgesic requirement. The patient was visited for epidural catheter removal 12 hours before discharge, and the catheter was removed. She was discharged with recommendations at the postoperative $38^{\text {th }}$ hour.

\section{DISCUSSION}

An increase in the incidence of hemodynamic changes, such as hormonal factors, as well as increased blood volume and cardiac output, is observed during pregnancy $(3,4)$. Advancements in the treatment of congenital heart diseases not only improve the lifespan and quality of life of patients but also result in an increase in pregnancy rates in these patients (4). As reported in the literature, patients tolerate pregnancy well with a treatment that takes into consideration the teratogenic effects of the pharmacological agents used after the surgical treatment of TOF, which is the most commonly observed cyanotic congenital heart disease $(5,6)$.

Patients with repaired TOF may exhibit residual cardiac diseases such as dysrhythmias, pulmonary vascular anomalies, right or left ventricular failure or residual right ventricular outflow tract obstruction. The anatomy, physiology and cardiac history of each patient with repaired TOF are variable. Therefore, there is no single formula for pregnancy and delivery management for all repaired TOF patients (7). The anesthetist should consider reviewing the patient's cardiovascular testing, including ECO findings, before admission for delivery to develop an intrapartum care plan. Patients should be carefully examined and monitored to minimize the risk of neuraxial block and maximize benefits (8). For this reason, we performed an ECO evaluation of our patient, as well as a strict hemodynamic follow-up, and we performed IBP monitorization for early recognition of blood pressure changes.

Several reports in the literature have stated that vaginal delivery is preferable for most patients with surgically repaired TOF $(7,9)$. Although there are many recommendations, there is no standard technique for anesthesia in pregnant women with cardiac diseases. General anesthesia offers the benefit of better oxygenation. However, there is a risk of adverse hemodynamic responses associated with laryngoscopy and the possibility of airway complications such as aspiration and difficult intubation in pregnancy (7). According to the obtained data, single-dose spinal anesthe- 
sia is not recommended for pregnant women with TOF. It is stated that epidural anesthesia or spino-epidural anesthesia is more beneficial even in pregnant women with the most severe cardiac diseases (9). We preferred epidural anesthesia and analgesia to minimize hemodynamic fluctuations and catecholamines by providing intraoperative hemodynamic stability and postoperative analgesia.

It is important to choose the agents and doses used carefully for a safe neuraxial blockade in pregnant women with heart disease. Therefore, using increasing doses of a slow-acting local anesthetic while controlling hemodynamic parameters helps the anesthesia settle gradually, thereby providing better preservation of cardiovascular stability (10). Therefore, bupivacaine was administered to our patient in 5-minute intervals.

If there is no problem in the health of the mother, mothers who have a normal vaginal delivery are discharged in 24-48 hours, and mothers who give birth by cesarean section in 24-96 hours. Early discharge is the discharge of the puerperant in 24 hours or less after vaginal delivery and in 48 hours or less after cesarean delivery (11). The World Health Organization recommends that mothers should receive care in a health institution for at least 24 hours in the postpartum period (12). Since postpartum early discharge has many advantages for mother and baby, it is observed that discharge times after cesarean section are frequently 24-48 hours in our institution. In our study, it was observed that the mother who gave birth to a healthy baby was discharged at the $38^{\text {th }}$ hour, since there was no problem in the follow-up.

In conclusion, we suppose that application of epidural anesthesia with divided and increasing doses of slow-acting bupivacaine in pregnant women with repaired TOF is a safe alternative to achieve good anesthesia with effective cardiovascular stability. Additionally, we believe that providing postoperative analgesia via an epidural catheter may prevent adverse effects such as tachycardia, hypertension and agitation. However, we consider that our data should be supported by the reports of more recent studies.

Acknowledgment

None

Author Contrubitons

Concept: Gamze Küçükosman, Bahar Say, Design: Gamze Küçükosman, Bahar Say, Data Collection or Processing: Bahar Say, Literature Search: Gamze Küçükosman, Bahar Say, Writing: Gamze Küçükosman, Bahar Say.

\section{Conflicts of Interest}

The authors do not have any conflict of interest.

\section{Financial Support}

No financial support has been received for our case report.

\section{Ethical Approval and Informed Consent}

Since it was a case report, ethics committee approval was not required. Patient consent was obtained.

\section{Peer Review Process}

Extremely peer-reviewed.

\section{REFERENCES}

1. Lake CL, editor. 3rd ed. Stamford, CT: Appleton and Lange; 1998. Paediatric cardiac anaesthesia .Stamford, CT: Appleton and Lange, 1998; 305-306.

2. Arendt KW, Fernandes SM, Khairy P, Warnes CA, Rose $\mathrm{CH}$, Landzberg MJ, Craigo PA, Hebl JR. A case series of the anesthetic management of parturients with surgically repaired tetralogy of fallot. Anesth Analg 2011;113:307-317.

3. Yeomans ER, Gilpstrap LC. Physiologic changes in pregnancy and their impact on critical care. Crit Care Med 2005;33:256258.

4. Lin $\mathrm{CH}$, Lee $\mathrm{CN}$. Atrial fibrillation with rapid ventricular response in pregnancy. Taiwan J Obstet Gynecol 2008;47:327-323.

5. Pedersen LM, Pedersen TA, Ravn HB, Hjortdal VE. Outcomes of pregnancy in women with tetralogy of Fallot. Cardiol Young 2008; 18: 423-429.

6. Veldtman GR, Connolly HM, Grogan M, Ammash NM, Warnes CA. Outcomes of pregnancy in women with tetralogy of Fallot. J Am Coll Cardiol 2004;44:174-180.

7. Warnes CA, Williams RG, Bashore TM, Child JS, Connolly HM, Dearani JA, del Nido P, Fasules JW, Graham TP Jr, Hijazi ZM, Hunt SA, King ME, Landzberg MJ, Miner PD, Radford MJ, Walsh EP, Webb GD. ACC/AHA 2008 guidelines for the management of adults with congenital heart disease: a report of the American College of Cardiology/American Heart Association Task Force on practice guidelines (Writing Committee to Develop Guidelines on the Management of Adults with Congenital Heart Disease): Developed in collaboration with the American Society of Echocardiography, Heart Rhythm Society, International Society for Adult Congenital Heart Disease, Society for Cardiovascular Angiography and Interventions, and Society of Thoracic Surgeons. Circulation 2008;118: e714-833.

8. Gomar C, Errando CL. Neuroaxial anaesthesia in obstetrical patients with cardiac disease. Curr Opin Anaesthesiol 2005;18:507-512.

9. Siu SC, Colman JM. Heart disease and pregnancy. Heart 2001;85:710.

10. Hamlyn EL, Douglass CA, Plaat F, Crowhurst JA, Stocks GM. Low-dose sequential combined spinal-epidural: An anaesthetic technique for caesarean section in patients with significant cardiac disease. Int J Obstet Anesth 2005;14:355-361.

11. Karaçam Z. Normal postpartum dönemin fizyolojisi ve bakımı. Şirin A, Kavlak O, editörler. Kadın Sağlığı. Genişletilmiş 2. Baskı. İstanbul: Nobel Tıp Kitabevleri; 2015. 460-87.

12. World Health Organization (WHO). Recommendations on postnatal care of the mother and newborn, a practical guide, 2013. Geneva: WHO. ISBN:9789241506649. 2013. 